\title{
Synthesis of Polymer Brushes by Surface-Initiated Controlled/Living Free Radical Polymerization Techniques
}

\section{Yüzeyde Başlatılan Kontrollü/Yaşayan Serbest Radikal Polimerizasyon Teknikleriyle Polimer Fırçaların Sentezi}

\author{
Kübra Özkan Hüküm ${ }^{1 \oplus}$, Esma Mutlutürk ${ }^{1 \oplus}$, Tuğba Demir Çalışkan ${ }^{2 \oplus}$ and Tuncer Çaykara ${ }^{1^{*} \odot}$ \\ ${ }^{1}$ Department of Chemistry, Faculty of Science, Gazi University, Besevler, Ankara, Turkey. \\ ${ }^{2}$ Department of Chemical Engineering, Faculty of Engineering, Ankara University, Tandogan, Ankara, Turkey.
}

\section{A BSTRACT}

\begin{abstract}
The surface modifications are necessary to alter the inherent surface physical/chemical properties of materials in terms of adhesion, wettability, friction, biocompatibility etc. for using in textile, electronic and biomedical industries. Surface modifications are usually made by grafting of polymer brushes to the solid substrates. The grafting process allows controlling and manipulation of surface properties without changing the chemical structure of polymers. Besides their chemical structures, grafting density of polymer brushes and average distance between the polymer chains attached to the surface are also important parameters, affecting the intended use of the grafted materials. Synthesis of functional polymer brushes is generally carried out by one of surface-initiated controlled/living free radical polymerization techniques, namely Atom Transfer Radical Polymerization (ATRP), Nitroxide-Mediated Polymerization (NMP), Photoiniferter-Mediated Polymerization (PIMP) and Reversible Addition-Fragmentation Chain Transfer Polymerization (RAFT). This review reports the strategies of these techniques for generating polymer brushes and summarizes the applications of polymer brushes in multiple fields.
\end{abstract}

\section{Key Words}

Polymer brushes, atom transfer radical polymerization, nitroxide-mediated polymerization, photoiniferter-mediated polymerization, reversible addition-fragmentation chain transfer polymerization.

\section{öz}

\begin{abstract}
üzey modifikasyonları, tekstil, elektronik, biyomedikal gibi uygulamalarda kullanılması üzere malzeme yüzeylerinin yapışma, ıslanabilirlik, sürtünme, biyouyumluluk vb. fiziksel ve kimyasal özelliklerini değiştirmek için gereklidir. Yüzey modifikasyonları genellikle katı substratlara polimer zincirlerinin aşılanmasıyla yapılır. Aşılama işlemi, polimerlerin kimyasal yapısını değiştirmeden yüzey özelliklerinin kontrolüne ve manipülasyonuna izin verir. Polimer fırçalarının kimyasal yapısının yanısıra, onların aşılanma yoğunluğu ve yüzeye tutturulmuş polimer zincirleri arasındaki ortalama mesafe de aşılanmış malzemelerin kullanım amacını etkileyen önemli parametrelerdir. Aşılı polimerlerin yüzey fonksiyonları aşılama tekniklerinin seçilmesiyle karakterize edilir. Fonksiyonel polimer fırçaların sentezi genellikle yüzeyde başlatılan kontrollü/yaşayan serbest radikal polimerizasyon tekniklerinden biri, yani Atom Transferi Radikal Polimerizasyonu (ATRP), Nitroksit Aracılı Polimerizasyon (NMP), Fotoiniferter Aracılı Polimerizasyon (PIMP) ve Tersinir Katılma Ayrılma Zincir Transfer Polimerizasyonu (RAFT) ile gerçekleştirilir. Bu derleme makalesinde, polimer fırçaların üretilmesinde kullanılan bu tekniklerin stratejileri rapor edilecek ve çeşitli alanlarda uygulanması özetlenecektir.
\end{abstract}

\section{Anahtar Kelimeler}

Polimer fırçalar, atom transferi radikal polimerizasyonu, nitroksit aracılı polimerizasyon, fotoiniferter aracılı polimerizasyon, tersinir katılma ayrılma zincir transfer polimerizasyonu. 


\section{INTRODUCTION}

D olymer brushes become more popular due to their potential applications in multiple fields, such as surface modifications [1-4], biomedical engineering [58], etc. They are densely grafted polymer chains with one end attached to the surface or interface of silicon wafers, glass, gold particles or polymer substrates [911]. For several years, innovative research in polymer brushes has not entered the field of polymer science anymore, it has also begun to enter the field of physical chemistry, nanomaterial science, and biotechnology. This transformation is catalyzed by using one of surfaceinitiated controlled/living free radical polymerization techniques, namely Atom Transfer Radical Polymerization (ATRP) [12-14], Nitroxide-Mediated Polymerization (NMP) [15-19], Photoiniferter-Mediated Polymerization (PIMP) [20-22], and Reversible Addition-Fragmentation Chain Transfer Polymerization (RAFT) [23-26]. These techniques bring less demanding synthetic strategies that facilitate access to a specialty that is believed to be the exclusive area of polymer brushes to date.

Polymer brushes with variable conformations and structures enable the changes of physical properties of film surfaces. Therefore, surface properties of polymer films depend not only on the type of polymer but also on grafting density, thickness, and hydrophilicity of the grafted polymer films. The grafting parameters of the polymer brushes are determined using the following equations [17].

$$
\begin{aligned}
& v=\frac{h \cdot r N_{A} 10^{-21}}{\bar{M}_{n}} \\
& D=\left(\frac{4}{r v}\right)^{1 / 2} \\
& R_{g}=a\left(\frac{\overline{D P}_{n}}{6}\right)^{1 / 2}
\end{aligned}
$$

where $h$, ellipsometric film thickness $(\mathrm{nm}) ; \mathrm{r}$, density of polymer $\left(\mathrm{g} \mathrm{cm}^{-3}\right) ; N_{A^{\prime}}$ Avogadro's number and $\bar{M}_{n}$, is number average molecular mass of polymer $\left(\mathrm{g} \mathrm{mol}^{-1}\right), a$ is statistical segment length $(\mathrm{nm})$ and degree of polymerization $\left(\overline{\mathrm{DP}_{\mathrm{n}}}\right)$.
The grafting density plays an important role in determining the conformation state, that is, a "mushroom" or a "brush" state. If the distance between polymer chains attached to the surface is less than twice the gyration radius of the macromolecule $\left(D<2 R_{g}\right)$, the polymer chains are in brush conformation, and if it is large $\left(D>2 R_{g}\right)$ mushroom conformation [27]. However, the term "polymer brush" should be associated with a layer of attached polymer chains under specific conditions when the state of attached layer is dictated by strong interactions between densely grafted polymer chains. The polymer brushes with moderate-to-high grafting densities imparted different properties than brushes with low grafting density $[28,29]$. The grafting density is controlled using surface-initiated controlled/living free radical polymerization techniques. In general, the grafting density of polymer brushes synthesized through the surface-initiated controlled/living free radical polymerization was higher than those obtained by the free radical polymerization. In this review article, we summarize several studies focused on the relations between the grafting density, thickness, and hydrophilicity of the polymer brushes, their properties and surfaceinitiated controlled/living free radical polymerization techniques.

\section{1- Surface-Initiated Atom Transfer Radical Polymerization (SI-ATRP)}

ATRP is one of the most important methods for the formation of polymer brushes via surface-initiated polymerization. This polymerization method is based on the reversible redox activation of a dormant alkyl halide terminated polymer chain end with a halogen transfer to a transition metal complex. This reaction leads to the homolytic breakage of the carbon-halogen bond, so that free radical species are formed at the polymer chain end. The activation step involves the transfer of an electron from the transition metal complex to the halogen atom, leading to the oxidation of the transition metal complex. The rate of ATRP reaction is highly dependent on catalyst concentration, ligand type, solvent and initiator [30].

We reported the synthesis of thermoresponsive poly $(\mathrm{N}$ isopropylacrylamide) [poly(NIPAM)] brushes from 2-bromopropionyl bromide (2-BPB) self-assembled monolayers (SAMs) on silicon substrate using $\mathrm{Cu}(\mathrm{I}) \mathrm{Br} / 2,2^{\prime}-$ bipyridine catalyst to control the radical concentration via SI-ATRP (Scheme 1) [31]. 


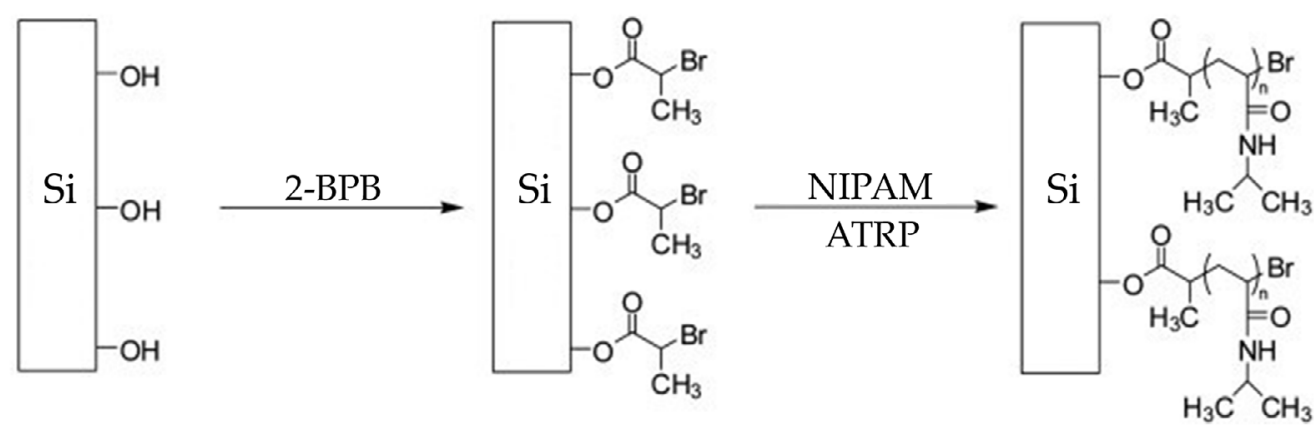

Scheme 1. The synthesis of poly(NIPAM) brushes via SI-ATRP from 2-bromopropionyl bromide-SAMs on silicon wafer [31].

Water contact angle measurements of the poly(NIPAM) brushes displayed a two-stage increase upon heating over the board temperature range $25-45^{\circ} \mathrm{C}$, which is in contrast to the fact that free poly(NIPAM) homopolymers in aqueous solution demonstrate a phase transition at $34^{\circ} \mathrm{C}$ (Figure 1) [31]. The first de-wetting transition takes place at $27^{\circ} \mathrm{C}$, which can be attributed to the $n$-cluster induced collapse of the inner region of poly(NIPAM) brush close to the silicon surface; the second de-wetting transition occurs at $38^{\circ} \mathrm{C}$, which can be attributed to the outer region of poly(NIPAM) brush, having much lower chain density compared to that of the inner part [31].

\section{2- Surface-Initiated Nitroxide-Mediated}

\section{Polymerization (SI-NMP)}

SI-NMP creates a living polymerization technique based on reversible closing of an active chain-end radi- cal with a nitroxide leaving group. The first successful application of this technique to synthesize poly(styrene) brushes was made by Husseman. et al. [32]. They used silicon wafers with alkoxyamine initiator SAMs to grow poly(styrene) brushes on silicon wafers. The propagation mechanism of polymer chains is based on heating the initiator functionalized wafer to $120^{\circ} \mathrm{C}$, in order to cleave off the alkoxyamine moiety, with the subsequent release of an alkyl radical and stable nitroxide radical, 2,2,6,6-tetramethylpiperidin-1-yl) oxidanyl (TEMPO) (Scheme 2). The propagation is controlled by the reversible "capping" of the growing chain by the TEMPO radical, thereby giving a "living character" to the polymerization.

It is well known that SI-NMP is efficient method for the growing of polymer brushes from various substrates such as silicon oxides, metals, mineral clays and car-
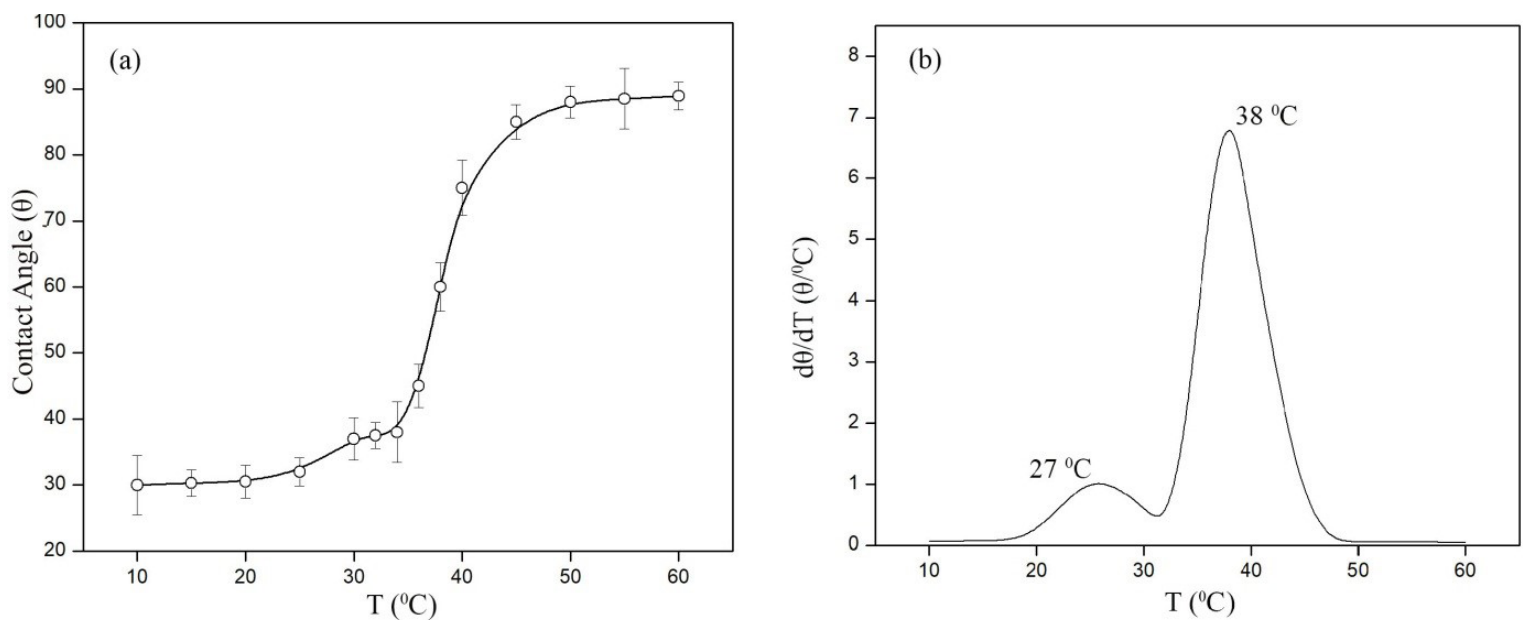

Figure 1. (a) Temperature-dependence of water contact angles of poly(NIPAM) brushes on the silicon substrate and (b) Derivative curve of $d \theta / d T$ versus $T$. Data points are an average of five measurements taken at different points along the sample surface [31]. 
<smiles>CCO[Si](C)(O)O[Si](CCc1ccccc1)(ON1C(C)(C)CCCC1(C)C)O[Si](C)(O)OCC</smiles>

Fixed alkoxyamine initiator<smiles>C=Cc1ccc(CCCC)cc1</smiles>

$120^{\circ} \mathrm{C}$<smiles>CCO[Si](C)(C)O[Si](CC(CC)(CC(C)(C)c1ccccc1)c1ccccc1)(ON1C(C)(C)CCCC1(C)C)O[Si](C)(O)OCC</smiles>

Grafted poly(styrene)

Scheme 2. Scheme describing the synthesis of poly(styrene) brushes by SI-NMP [32].

bon-based materials [33-38]. For instance, we first time prepared the well-defined oligo- $N$-isopropylacrylamide (oligoNIPAM) brushes with -OH and - $\mathrm{COOH}$ end-groups by the combination of the self-assembly of bimolecular macroazoinitiator on silicon surface and SI-NMP of $\mathrm{N}$ isopropylacrylamide in the presence of chain transfer agent (i.e., 2-mercaptoethanol or 3-mercaptopropionic acid) [39]. The oligoNIPAM brushes with a grafting density as 8.14 chains $/ \mathrm{nm}^{2}$ was synthesized. AFM images of polymer brushes with $-\mathrm{OH}$ and $-\mathrm{COOH}$ end -groups are shown in Figure 2. It is clearly seen that the morphology of surface significantly changes when needlelike oligoNIPAM brushes homogeneously distributed over the entire surface. Although the morphology of oligoNIPAM-OH and oligoNIPAM-COOH brushes are similar to the oligoNIPAM ones, the roughness of brushes changes in the presence of chain transfer agent. The ro- ughness of oligoNIPAM brushes was $1.46 \mathrm{~nm}$, whereas those of oligoNIPAM-OH and oligoNIPAM-COOH brushes were 0.78 and $1.01 \mathrm{~nm}$, respectively [39].

Graphene surfaces are also grafted with polymer brushes via SI-NMP technique. Garcie et al. used a two-step procedure (i) modification of graphene oxide surface with oxoammonium salt and (ii) graft polymerization of isoprene or styrene from the TEMPO-functionlized surface at $130^{\circ} \mathrm{C}$. According to TGA data, they obtained approximately $34 \%$ poly(styrene) and $68 \%$ polyisoprene [poly(IP)] on the graphene surfaces [40]. Figure 3 illustrates the STEM image of graphine oxide (GO) and TEM image of GO-g-poly(styrene)-T) nanocomposite. Exfloliated, crumbled or folded graphene oxide sheets or layers are seen in Figure 3a. After graft polymerization, the layered or folded sheet structure of GO is not chan-

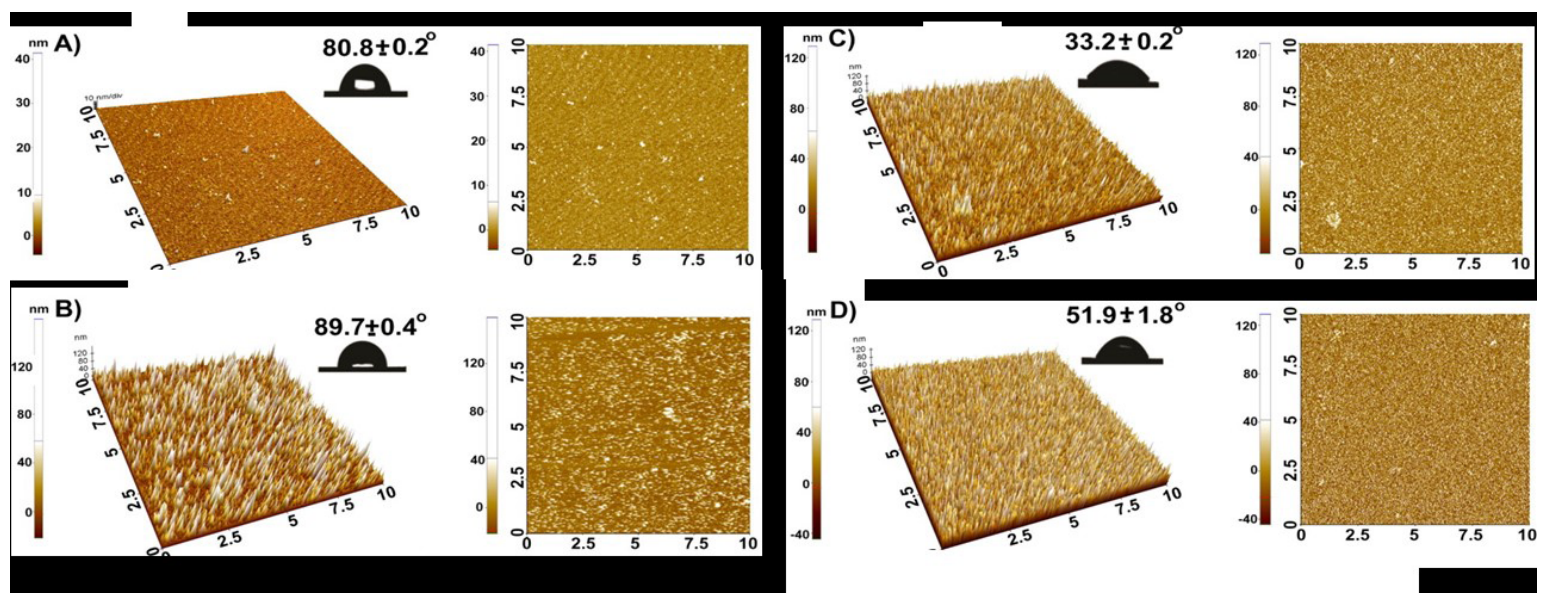

Figure 2. 3D (left) and $2 D$ (right) AFM topography images $\left(10 \times 10 \mu \mathrm{m}^{2}\right.$, z scale is $\left.10 \mathrm{~nm}\right)$ in ambient conditions and photographs of $4 \mu \mathrm{L}$ water droplets (top) on the bimolecular macroazoinitiator-immobilized silicon (A), oligoNIPAM (B), oligoNIPAM-COOH (C), and oligoNIPAM-OH (D) [39]. 
ged but $\mathrm{nm}$ sized polymer brushes (black spots) were formed on the GO surface (Figure $3 b$ ).

\section{3- Surface-Initiated Photoiniferter-Mediated Polymerization (SI-PIMP)}

SI-PIMP is a technique based on the use of a special type of initiators called "iniferters." These iniferters are molecules that display unique properties provided that they can act as initiators, transfer agents, and terminators at the same time. Generally, dithiocarbamate derivative molecules are capable of acting as photoiniferters as and they act as initiators, transfer agents or terminators during the UV induced polymerization. When exposed to UV light, photoiniferter molecules are photolyzed, giving a carbon radical and a dithiocarbamate radical. While the carbon radical is reactive and

a)

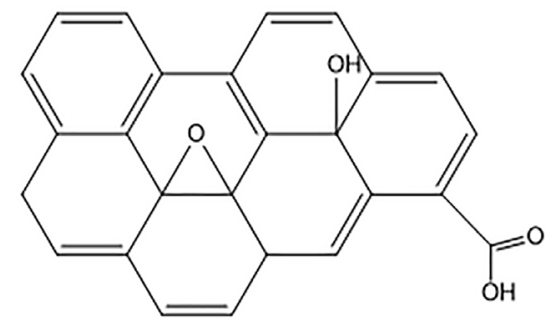

b)

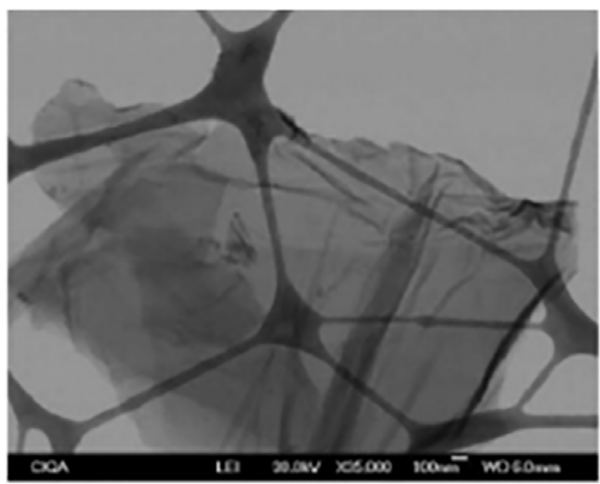

can react with monomers and initiate polymerization, the thiocarbamate radical is stable and reacts weakly, also the monomers [41]. By the way, the thiocarbamate radical can reversibly terminate the growing chains, thereby giving "living" properties to photoiniferter-mediated polymerization (Scheme 3). Regularly, the carbon radical on photolysis provides addition of monomers to initiate chain propagation and simultaneously the dithiocarbamate radical acts as a transfer agent causing reversible termination of the propagating chains (Scheme 3). This interesting strategy was used to synthesize poly(2-(dimethylamino)ethyl methacrylate) [poly(DMAEMA)] brushes from mesoporous materials modified with $\mathrm{N}, \mathrm{N}$-(diethylamino) dithiocarbamoylbenzyl (trimethoxy)silane (SBDC) moieties by AndrieuBrunsen et al. [42]. Due to the photosensitive nature c)

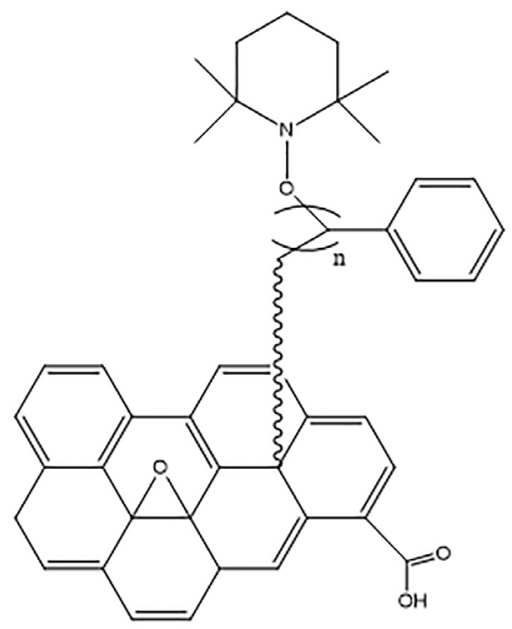

d)

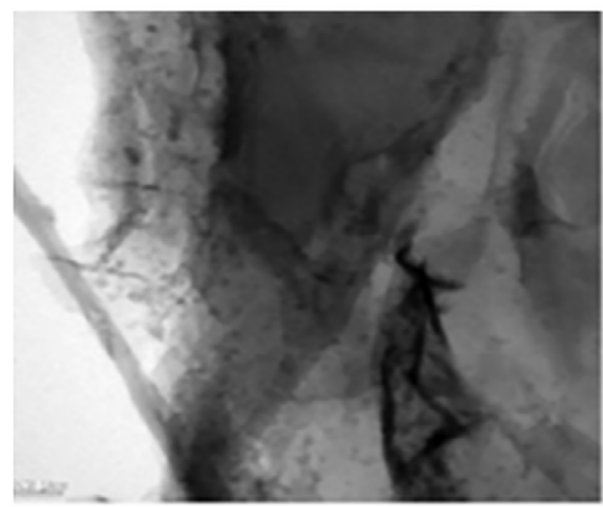

Figure 3. Chemical structure of (a) GO, and (c) GO-g-poly(styrene)-T; (b) STEM image of GO on lacey carbon; (d) TEM image of GO-gpoly(styrene)-T [40]. 
of the iniferter molecules, SI-PIMP can be spatially and temporally controlled by manipulating the location, intensity, and duration of UV light $[43,44]$.

SI-PIMP provides dense polymer brushes grown from substrates. Several studies proved that the thickness of polymer brushes obtained via SI-PIMP depends on photiniferter coverage on surface, monomer concentration and UV irradiation time $[45,46]$. Edmonto et al. synthesized poly(methacrylic acid) poly(MAA) brushes from self-assembled monolayers (SAMs) of photiniferter molecules on gold surface to investigate the effects of initiator coverage on polymer brush thickness

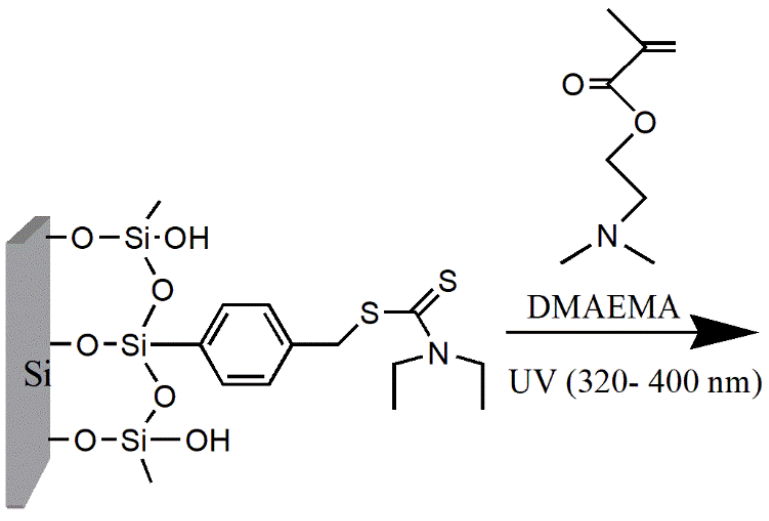

Fixed iniferter

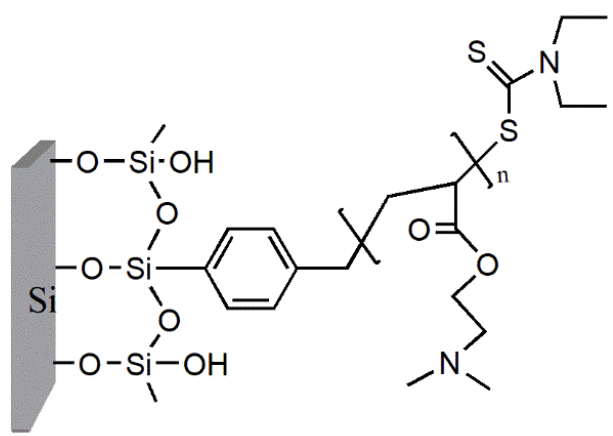

Grafted poly(DMAEMA)

Scheme 3. Scheme describing the synthesis of poly(DMAEMA) brushes from mesoporous materials modified with SBDC via SI-PIMP [42].

[45]. The disulfide photoinitiator dithiodiundecane11,1diylbis[4(\{[(diethylamino)carbonothioyl] thioethyl) phenyl]carbamate\} (DTCA) and 1,2-dioctadecyldisulfane (DDS) were used for polymerizations. They found that although the brush thickness growth rate does not depend on DTCA and/or DDS coverage, their composition on the gold surface significantly influence the morphology of polymer brush films. It is expected since concentrated SAMs on the surface results in higher number of grafted chains, leading to dense polymer brushes. Furthermore, they calculated the total mass of poly(MAA) $\left(\mathrm{ng} / \mathrm{cm}^{2}\right)$ on quartz crystal as a function of polymerization time using the QCM measurements. Figure 4 illustrates that total film mass of poly(MAA) grafted from 1.0 DTCA exhibited higher polymer brush growth compared with that of the 0.2 DTCA during 20 min polymerization. In other words, grafting density of poly(MAA) brushes increases with increasing the DTCA concentration on the surface, leading to higher roughness [45].
SI-PIMP also offers great promise for many application, especially medical application (i.e. antigen detection) due to the lacking of requirement of a toxic catalyst. Jiao et al. prepared two-layered brushes on inert cycloolefin polymer (COP) supports for use in antigen detection. These brushes possess dual functions such as a low fouling poly(ethylene glycol)methacrylate) (poly(EGMA)) bottom layer and a poly(acrylic acid) (poly(AA)) upper layer for antibody loading [47]. Sodium diethyldithiocarbamate trihydrate photoiniferter was deposited on COPs and EGMA and AA monomers were polymerized under UV light (high-pressure mercury lamp, $400 \mathrm{~W}$, main wavelength $380 \mathrm{~nm}$ ) from surface. Then, they modified COP-g-poly(AA) and COP-g-poly(EGMA)- $b$ poly(AA) supports with antibodies for use in antigen detection. According to fluorescent images of polymer brushes with antibody and target antigen (Figure 5), it was found that COP-g-poly(EGMA)- $b$-poly(AA)-IgG support had a better capability of antigen recognition relative to the COP-g-poly(AA)-IgG. 


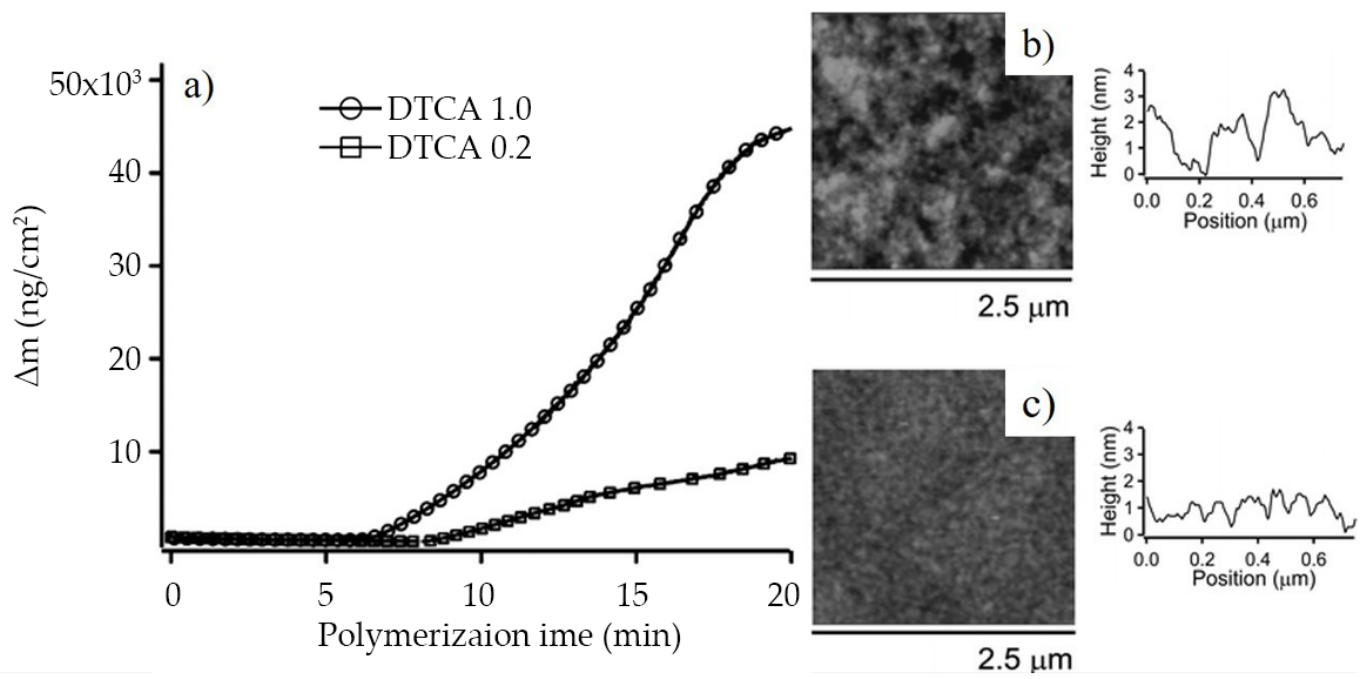

Figure 4. (a) Hydrated mass uptake (expressed as $\mathrm{ng} / \mathrm{cm}^{2}$ ) estimated by fitting $\Delta f$ and $\Delta D$ values obtained during the photopolymerization of poly(MAA) to a Voigt model for the adsorbed film for 1.0 (०) and 0.2 ( $\square$ ) SAMs, respectively. High-resolution topography images by TM-AFM for layers grafted from (b) 1.0 SAMs and (c) 0.2 SAMs the corresponding cross-sectional profile is given near them. (vertical scale from black to white $10 \mathrm{~nm}$ ) [45].

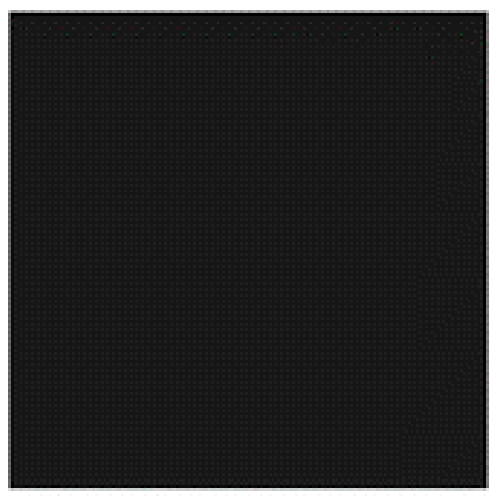

a-1

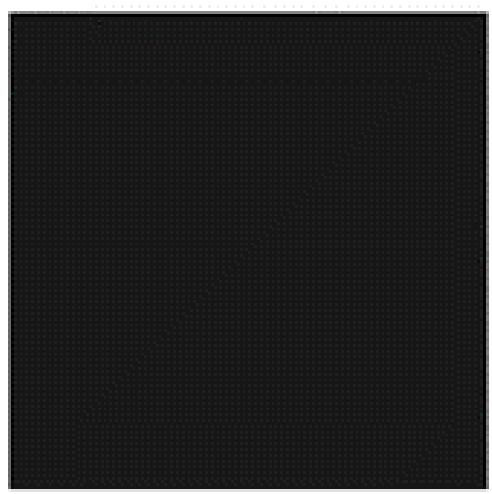

a-2

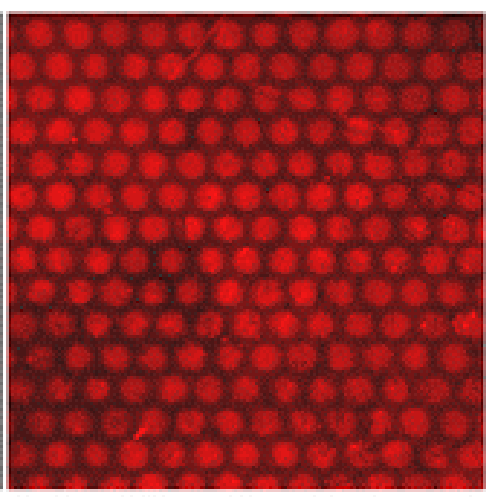

b-1

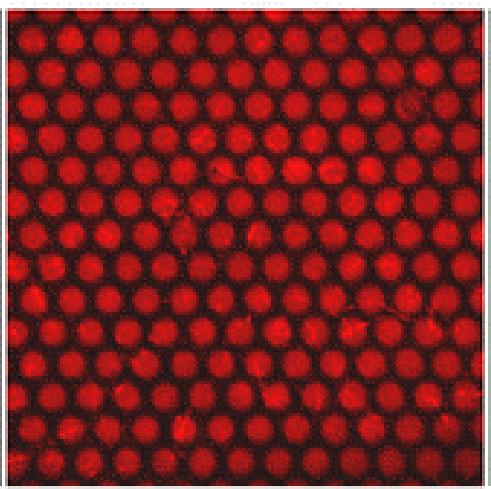

b-2

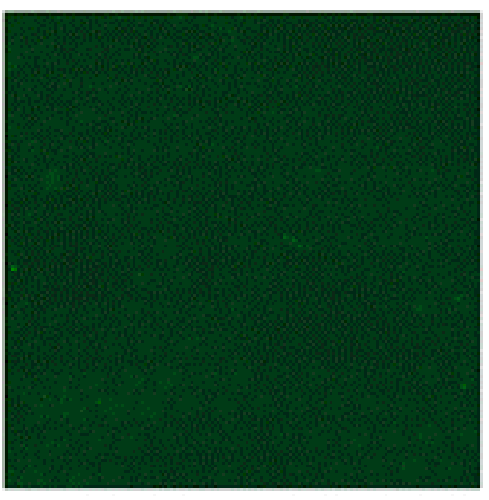

c-1

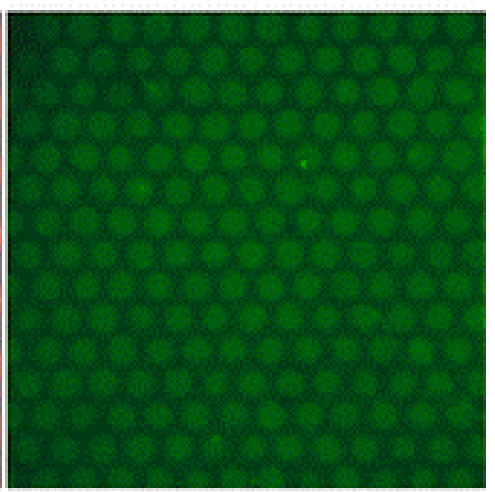

c-2

Figure 5. Fluorescent images of polymer brush microarrays (a), antibody-immobilized microarrays (b), and microarrays with target antigen (c): (1) COP-g-poly(AA) 8 min; (2) COP-g-poly(EGMA) 12 min $-b$-poly(AA) ${ }_{8 \text { min }}$. [47]. 


\section{4- Surface-Initiated Reversible-Addition Fragmentation Chain Transfer (RAFT) Polymerization}

RAFT polymerization is a controlled/living polymerization technique in which chain growth is initiated using a free radical initiator, for example, azobisisobutyronitrile (AIBN), and mediated by a chain transfer agent (CTA) constituted of dithioester, dithiocarbamate, or trithiocarbcarbonate compounds $[48,49]$. In this technique, radical transfer between growing chains is responsible for providing good control over the polymerization process. Contaminantly, the "capping" of growing chains by the dithioester moiety confers good living characteristics to the polymerization reaction.
In most cases, the generation of polymer brushes via SIRAFT polymerization involved the use of either surfaceimmobilized conventional free radical initiators or surface-immobilized RAFT agents. To obtain the high bonding density of the initiator-containing self-assembled monolayers (SAMs), firstly, the interlinker molecule bearing a long chain alkyl thiol (for a gold surface) or siloxane/chlorosilane (for a silicon/glass/indium-thin oxide surface) with a suitable end group should be immobilized on the substrate surface. Especially, a SAM containing an epoxy/amine/hydroxyl end group is useful to directly immobilize carboxylic acid bearing initiator. In the surface-initiated RAFT polymerization, the polymer brush layer is generated in situ from a suitable
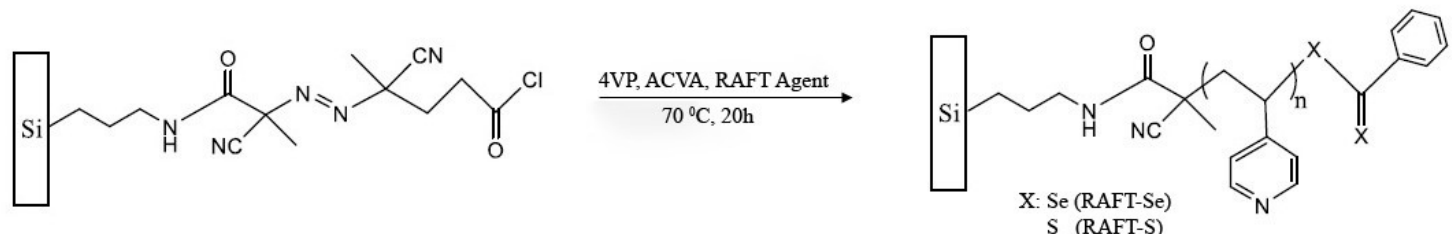

Scheme 4. Schematic diagram illustrating the process of the surface-initiated RAFT polymerization of 4VP from the Si-Azo surface [50].

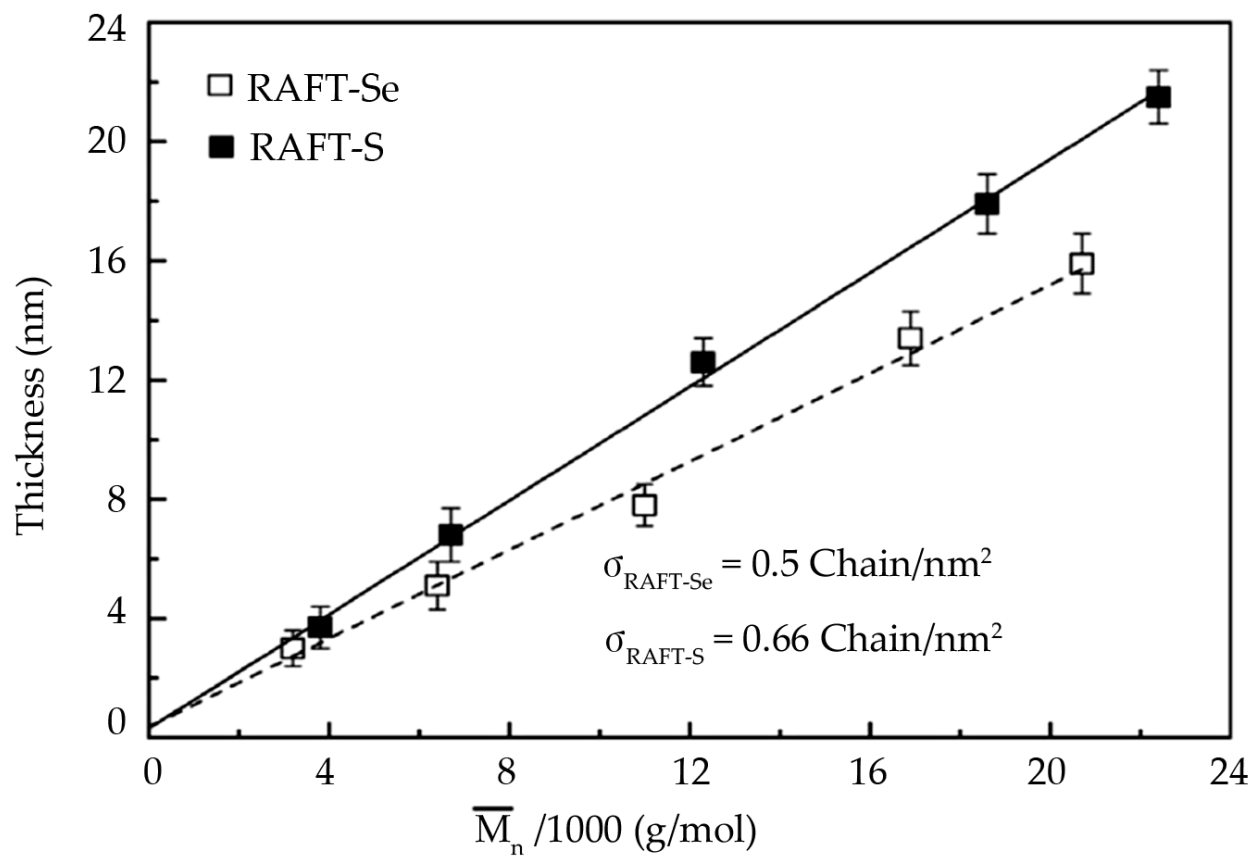

Figure 6. Evolution of the thickness ( $h, n m$ ) of the poly(4VP) brushes synthesized in the presence of RAFT-Se and RAFT-S as a function of $M_{n}[50]$. 
surface-immobilized initiator $[48,49]$. We synthesized the poly(4-vinylpyridine) [poly(4VP)] brushes by using a new selenium-based RAFT agent (4-cyanopentanoic acid diselenobenzoate, RAFT-Se) in the surface-initiated RAFT polymerization (Scheme 4) [50].

RAFT polymerization involves a reversible additionfragmentation cycle, in which transfer of the dithioester groups between the activated and dormant polymer chains mains the controlled character of the polymerization process. Because of the analog of selenium (Se) with sulfur (S) in an electronic structure, RAFT-Se is also useful for RAFT polymerization. The surface-initiated RAFT polymerization using the RAFT-Se is the same polymerization mechanism as its analog, 4-cyanopentanoic acid dithiobenzoate (RAFT-S).

The relationship between the thickness ( $h, n m)$ of poly((4VP) brushes and $\bar{M}_{n}$ of the corresponding free polymers formed in the presence of RAFT-Se and RAFT-S is given in Figure 6. A direct proportion relationship was observed between the $\bar{M}_{n}$ and film thickness. From the slop of the thickness-versus- $\bar{M}_{n}$ curve, $\sigma$ of poly(4VP) synthesized in the presence of RAFT-Se $\left(\sigma_{\text {RAFT-Se }}\right)$ and RAFT-S ( $\left.\sigma_{\text {RAFT-S }}\right)$ was calculated to be 0.51
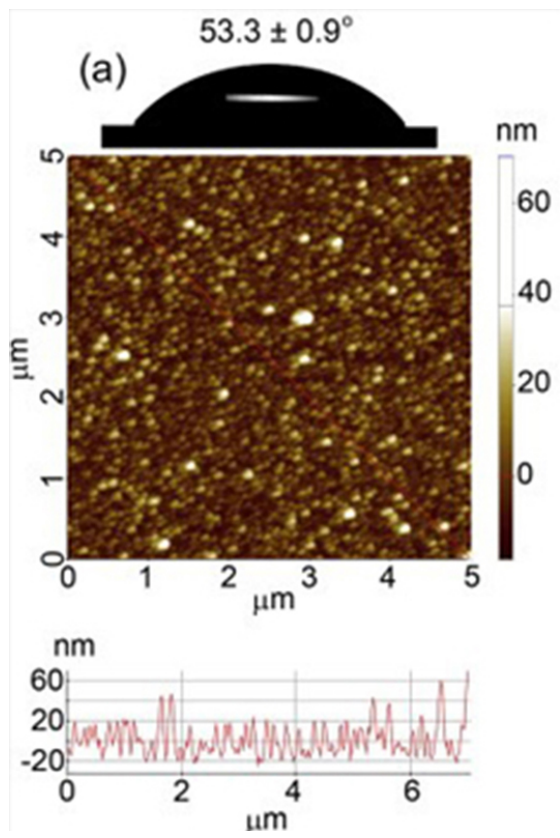

Figure 7. 2D AFM images $\left(5 \times 5 \mu \mathrm{m}^{2}\right)$ and photographs in ambient conditions of $4 \mathrm{~mL}$ water droplets (top) on the poly(4VP) brushes synthesized in the presence of RAFT-Se (a) and RAFT-S (b). The cross sections corresponding to the red line shown in the AFM images are given below each image [50]. and 0.66 chains $\mathrm{nm}^{-2}$, respectively. In the topographic AFM images of the poly(4VP) brushes prepared in the presence of RAFTSe and RAFT-S using the non-contact mode, the root-mean-square (rms) values of the surface roughness were found to be 4.18 and $3.23 \mathrm{~nm}$ in $5 \times 5$ $\mathrm{mm}^{2}$ scanning areas, respectively (Figure 5 ). No significant roughness differences were observed between the surfaces of the brushes prepared for both cases, suggesting the formation of homogeneous graft layers and hence homogeneity in grafting densities. The water contact angles of the poly(4VP) brushes prepared in the presence of RAFT-Se and RAFT-S were found to be $53.3 \pm 0.9^{\circ}$ ad $61.9 \pm 0.8^{\circ}$, respectively, meaning that the surfaces are hydrophilic. In the topographic AFM images of the poly(4VP) brushes prepared in the presence of RAFTSe and RAFT-S using the non-contact mode, the root-mean-square (rms) values of the surface roughness were found to be 4.18 and $3.23 \mathrm{~nm}$, respectively (Figure 7). No significant roughness differences were observed between the surfaces of the brushes prepared for both cases, suggesting the formation of homogeneous graft layers and hence homogeneity in grafting densities. The water contact angles of the poly(4VP) brushes prepared in the presence of RAFT-Se and RAFT-S were found to be $53.3 \pm 0.9^{\circ}$ ad $61.9 \pm 0.8^{\circ}$, respectively, meaning that the surfaces are hydrophilic.
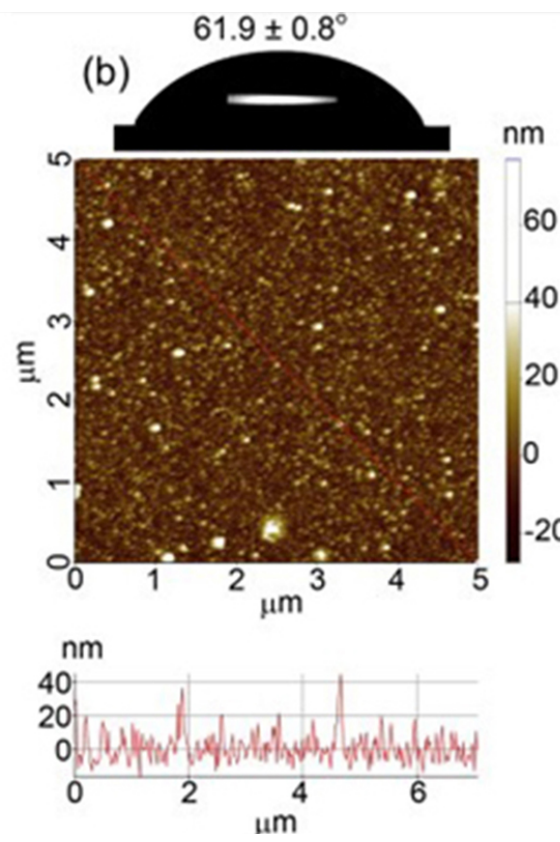


\section{Concluding Remarks}

In conclusion, a number of recent advances in the field of polymer brush synthesis by one of surface-initiated controlled/living free radical polymerization (NMP, ATRP, PIMP and RAFT) techniques described in this review article. Although the polymer brushes are synthesized predominantly on either silicon or gold surfaces, this field is constantly expanding to introduce onto magnetic nanoparticles, carbon nanotubes, polymer films, and a wealth of other materials. With the ability to polymerize, these materials by using any surface-initiated controlled/living free radical polymerization process, the possible combinations of substrates, synthesis approach, and polymerization route are providing numerous opportunities. Moreover, due to the high functional group tolerances of these techniques have been incorporated to a variety of substrates, thereby enabling the modification of surface properties.

\section{References}

1. T. Masuda, A.M. Akimoto, K. Nagase, T. Okano, R. Yoshida, Artifical cilia as autonomous nanoactuators: Desing of a gradient self-oscillating polymer brush with controlled unidirectional motion, Sci. Adv., 2 (2016) 1-7.

2. K.A. MOntey-Villages, A. Ramirez-Jimenez, A. Zizumbo-Lopez, S. Perez-Sicairos, B. Leal-Acevedo, E. Bucio, A. Licea-Claverie, Controlled surface modification of silicon rubber by gammairradiation followed by RAFT grafting polymerization, Eur. Polym. J., 134 (2020) 109817.

3. M. Li, C.W. Pester, Mixed polymer brushes for "smart" surfaces, Polymers, 12 (2020) 1553.

4. M. Bonnevide, T.N.T. Phan, N. Malicki, S.K. Kumar, M. Couty, D. Gigmes, J. Jestin, Synthesis of polyisoprene, polybutadiene and styrene butadiene rubber grafted silica nanoparticles by nitroxide-mediated polymerization, Polymer, 190 (2020) 122190.

5. M. Krishnamoorthy, S. Hakobyan, M. Ramstedt, J.E. Gautrot, Surface-initiated polymer brushes in the biomedical field: Applications in membrane science, biosensing, cell culture, regenerative medicine and antibacterial coatings, Chem. Rev., 114 (2014) 10976-11026.

6. K.B. Buhl, A.H. Agergaard, M. Lillethorup, J.P. Nikolajsen, S.U. Pedersen, K. Daasbjerg, Polymer brush coating and adhesion technology at scale, Polymers, 12 (2020) 1475.

7. W. Sun, W. Liu, Z. Wu, H. Chen, Chemical surface modification of polymeric biomaterials for biomedical applications, Macromol. Rapid Commun., 41 (2020) 1900430.

8. A.R. Kuzmyn, A.T. Nguyen, L.W. Teunissen, H. Zuilhof, J. Baggerman, Antifouling polymer brushes via oxygen-tolerant surface-initiated PET-RAFT, Langmuir, 36 (2020) 4439-4446.

9. S.T. Milner, Polymer brushes, Science, 251 (1991) 905-914.

10. S.S. Sheiko, B.S. Sumerlin, K. Matyjaszewki, Clyndrical molecular brushes: Synthesis, characterization, and properties, Prog. Polym. Sci., 33 (2008) 759-785.

11. C.M. Hui, J. Pietrasik, M. Schmitt, C. Mahoney, J. Choi, M.R. Bockstaller, K. Matyjaszewki, Surface-initiated polymerization as an enabling tool for multifunctional (nano-) engineered hybrid materials, Chem. Mater., 26 (2014) 745-762.
12. X. Huang, M.J. Wirth, Surface-initiated radical polymerization on porous silica, Anal. Chem., 69 (1997) 4577-4580.

13. A.K. Nanda, K. Matyjaszewki, Effect of $[$ bby $] /[\mathrm{Cu}(\mathrm{I})]$ ratio, solvent, counterion, and alkyl bromides on the activation rate constants in atom transfer radical polymerization, Macromolecules, 36 (2003) 599-604.

14. D.M. Jones, W.T.S. Huck, Controlled surface-initiated polymerizations in aqueous media, Adv. Mater., 13 (2001) 1256-1259.

15. L. Andruzzi, W. Senaratne, A. Hexemer, E.D. Sheets, B. Ilic, E.J. Kramer, B. Baird, C.K. Ober, Oligo(ethylene glycol) containing polymer brushes as bioselective surfaces, Langmuir, 21 (2005) 2495-2504.

16. R. Matsuno, K. Yamamoto, H. Otsuka, A. Takahara, Polystyreneand poly(3-vinylpridine)-grafted magnetite nanoparticles prepared through surface-initiated nitroxide-mediated radical polymerization, Macromolecules, 37 (2004) 2203-2209.

17. O. Guselnikova, S.R.A. Marque, E. Tretyakov, D. Mares, V. Jerabek, G. Audran, J.-P. Joly, M. Trusova, V. Svorcik, O. Lyutakov, et al., Unprecedented plasmon-induced nitroxide-mediated polymerization (PI-NMP): A method for preparation of functional surfaces, J. Mater. Chem. A, 7 (2019) 12414-12419.

18. V. Ladmiral, T. Morinaga, K. Ohno, T. Fukuda, Y. Tsujii, Synthesis of monodisperse zinc sulfide particles grafted with concentrated polystyrene brush by surface-initiated nitroxidemediated polymerization, Eur. Polym. J., 45 (2009) 2788-2796.

19. J.O. Zoppe, N.C. Ataman, P. Mocny, J. Wang, J. Moraes, H.A. Klok, Surface-initiated controlled radical polymerization: State-of-the-art, opportunities, and challenges in surface and interface engineering with polymer brushes, Chem. Rev., 117 (2017) 1105-1318.

20. H.J. Lee, Y. Nakayama, T. Matsuda, Spatio-resolved, macromolecular architectural surface: Highly branched graft polymer via photochemically driven quasiliving polymerization technique, Macromolecules, 32 (1999) 6989-6995.

21. S. Kidoaki, Y. Nakayama, T. Matsuda, Measurement of interaction forces between proteins and iniferter-based graftpolymerized surfaces with an atomic force microscope in an aqueous media, Langmuir,17 (2001) 1080-1087.

22. T. Matsuda, M. Kaneko, S. Ge, Quais-living surface graft polymerization with phosphorylcholine group(s) at the terminal end, Biomacromolecules, 24 (2003) 4507-4515.

23. W.H. Yu, E.T. Kang, K.G. Neoh, Functionalization of hydrogenterminated Si(100) substrate by surface-initiated RAFT polymerization of 4-vinylbenzyl chloride and subsequent derivatization for photoinduced metallization, Ind. Eng. Chem. Res., 43 (2004) 5194-5202.

24. A. Pourjavadi, M. Kohestanian, C. Streb, $\mathrm{pH}$ and thermal dual-responsive poly(NIPAM-co-CMA) coated magnetic nanoparticles via surface-initiated RAFT polymerization for controlled drug delivey, Mater. Sci. Eng., C, 108 (2020) 110418.

25. S. Demirci, A. Celebioglu, T. Uyar, Surface modification of electrospun cellulose acetate nanofibers via RAFT polymerization for DNA adsorption, Carbohydr. Polym., 113 (2014) 200-207.

26. I. Luzinov, D. Julthongpiput, H. Malz, V.V. Pionteck, Polystyrene layers grafted to epoxy-modified silicon surfaces, Macromolecules, 33 (2000) 1043-1048.

27. W.J. Brittain, S. Minko, A structural definition of polymer brushes, J. Polym. Sci., Part A: Polym. Chem., 45 (2007) 35053512.

28. S. Yamamoto, M. Ejaz, Y. Tsujii, T. Fukuda, Surface interaction forces of well-defined, high-density polymer brushes studied by atomic force microscopy. 2. effect of grafting density, Macromolecules, 33 (2000) 5608-5612. 
29. W.P. Liao, I.G. Elliott, R. Faller, T.L. Kuhl, Normal and shear interactions between high grafting density polymer brushes grown by atom transfer radical polymerization, Soft Matter, 9 (2013) 5753-5761

30. T.E. Pattern, K. Matyjaszewki, Copper(I) catalyzed atom transfer radical polymerization, Acc. Chem. Res., 32 (1999) 895-903.

31. E. Turan, S. Demirci, T. Caykara, Synthesis of thermoresponsive poly(N-isopropyl acrylamide) brushes on silicon wafer surface via atom transfer radical polymerization, Thin Solid Films, 518 (2010) 5950-5954.

32. M. Husseman, E.E. Malmström, M. McNamara, M. Mate, D. Mecerreyes, D.G. Benoit, J.L. Hedrick, P. Mansky, E. Huang, T.P. Russell, C.J. Hawker, Controlled synthesis of polymer brushes by "living" free radical polymerization techniques, Macromolecules, 32 (1999) 1424-1431.

33. A.C. Schmit, H. Turgut, D. Le, A. Beloqui, G. Delaittre, Making the best of it: Nitroxide-mediated polymerization of methacrylates via the copolymerization approach with functional styrenics, Polym. Chem., 11 (2020) 593-604

34. M. Ignatova, S. Voccia, B. Gilbert, N. Markova, P.S. Mercuri, M. Galleni, V. Sciannamea, S. Lenoir, D. Cossement, R. Gouttebaron, R. Jérôme, C. Jérôme, Synthesis of copolymer brushes endowed with adhesion to stainless steel surfaces and antibacterial properties by controlled nitroxide-mediated radical polymerization, Langmuir, 20 (2004) 10718-10726.

35. M. Joubert, A. Khoukh, J-F. Tranchant, F. Morvan, L. Billon, Hybrid aluminum colored pigments based on gradient copolymers design, Macromol. Chem. Phys., 210 (2009) 1544 1555.

36. L. Ghannam, M. Bacou, H. Garay, J. Francois, M.E.R. Shanahan, L. Billon, Elastomer monolayers adsorbed on mica surfaces by nitroxide-mediated polymerization, Polymer, 45 (2004) 70357045

37. C. Konn, F. Morel, E. Beyou, P. Chaumont, E. Bourgeat-Lami, Nitroxide-mediated polymerization of styrene initiated from the surface of laponite clay platelets, Macromolecules, 40 (2007) 7464-7472.

38. J. Li, X. Chen, Y-C. Chang, Preparation of end-grafted polymer brushes by nitroxide-mediated free radical polymerization of vaporized vinyl monomers, Langmuir, 21 (2005) 9562-9567.

39. D. Cimen, T. Çaykara, Preparation of oligo-N-isopropylacryl amide brushes with $-\mathrm{OH}$ and $-\mathrm{COOH}$ end-groups via surface initiated NMP, J. Appl. Polym. Sci., 129 (2013), 383-390.
40. O. Garcia-Valdez, R. Ledezma-Rodriguez, E. Sadivar-Guerra, L. Yate, S. Moya, R.F. Ziolo, Graphene oxide modification with graft polymers via nitroxide mediated radical polymerization, Polymer, 55 (2014) 2347-2355.

41. P. Lambrinos, M. Tardi, A. Polton, P. Sigwalt, The mechanism of the polymerization of n.butyl acrylate initiated with $\mathrm{N}, \mathrm{N}$ diethyl dithiocarbamate derivatives, Eur. Polym. J., 26 (1990) 1125-1135.

42. J.C. Tom, R. Brilmayer, J. Schidt, A. Andrieu-Brunsen, Optimization of surface-initiated photoiniferter-mediated polymerization under confinement, and the formation of block copolymers in mesoporous films, Polymers, 9 (2017) 539-560.

43. Y. Nakayama, T. Matsuda, Surface macromolecular architectural design using photo-graft copolymerization based on photochemistry of benzyl N,N-diethyldithiocarbamate, Macromolecules, 29 (1999) 8622-8630.

44. J. Higashi, Y. Nakayama, R.E. Marchant, T. Matsuda, Highspatioresolved microarchitectural surface prepared by photograft copolymerization using dithiocarbamate: Surface preparation and cellular responses, Langmuir, 15 (1999) 20802088.

45. E.M. Benetti, E. Reimhult, J. de Bruin, S. Zapotoczny, M. Textor, G.J. Vancso, Poly(methacrylic acid) grafts grown from designer surfaces: The effect of initiator coverage on polymerization kinetics, morphology and properties, Macromolecules, 42 (2009) 1640-1647.

46. E.M. Benetti, S. Zapotoczny, G.J. Vancso, Tunable thermoresponsive polymerica platforms on gold by "Photoiniferter"-Based surface grafting, Adv. Mater., 19 (2007) 268-271.

47. J. MA, S. Luan, L. Song, J. Jin, S. Yuan, S. Yan, H. Yang, H. Shi, J. Yin, Fabricating a cycloolefin polymer immunoassay platform with a dual-function polymer brush via a surface-initiated photoiniferter-mediated polymerization strategy, ACS Appl. Mater. Interf., 6 (2014) 1971-1978.

48. B. Zhao, W.J. Brittain, Polymer brushes: Surface-immobilized macromolecules, Prog. Polym. Sci., 25 (2003) 667-710.

49. K. Kato, E. Uchida, E.T. Kang, Y. Uyama, Y. Ikada, Polymer surface with graft chains Prog. Polym. Sci., 28 (2003) 209-259.

50. S. Demirci, S.K. Demirci, T. Çaykara, A new selenium-based RAFT agent for surface-initiated RAFT polymerization of 4-vinylpyridine, Polymer, 54 (2013) 5345-5350. 